\title{
A note on the occurrence of Arthrophycus in the Bell Island Group of eastern Newfoundland
}

\author{
Ron K. Pickerill, Denis Fillion* \\ Department of Geology, University of New Brunswick, Fredericton, New Brunswick E3B 5A3, Canada \\ and \\ Pat J. Brenchley \\ Department of Earth Sciences, University of Liverpool, Liverpool, England LG9 3BX
}

Date Received August 20, 1990

Date Accepted November 13, 1990

\section{INTRODUCTION}

In a recent monograph that described systematically the trace fossils of the Cambrian(?) to Early Ordovician trace fossils of the Bell Island and Wabana groups of Conception Bay, eastern Newfoundland (Fillion and Pickerill, 1990), we noted the remarkable similarity between these trace fossils and those previously described from coeval strata in France, Spain and Portugal. At the ichnogeneric level, one of the notable differences between eastern Newfoundland and these latter countries was the apparent absence in eastern Newfoundland of Arthrophycus Hall, 1852, Daedalus Rouault, 1850 and Volkichnium Pfeiffer, 1965. During the summer of 1989 , subsequent to the research originally undertaken by R.K.P and D.F., two of us (R.K.P. and P.J.B.) discovered a single specimen of Arthrophycus within the sequence. The purpose of this short note is, therefore, primarily to document this occurrence, but also to reiterate the "European" aspect of the ichnoassemblage as initially noted by Seilacher and Crimes (1969), Bergström (1976) and Pickerill and Fillion (1983, 1984) and more recently by Fillion and Pickerill (1990).

\section{LOCATION AND STRATIGRAPHY}

The Bell Island and Wabana groups are exposed on Bell Island, Litule Bell Island and Kellys Island in Conception Bay, eastern Newfoundland (Fig. 1). These groups have been subdivided by Ranger et al. (1984) into eleven formations, as indicated in Figure 1. The sequence is essentially Early Ordovician (Tremadoc-Arenig) in age though the basal portions could conceivably be latest Cambrian (Fillion and Pickerill, 1990). More detailed discussions on the stratigraphy and age of the succession have been undertaken by Bergström (1976), Pickerill and Fillion
(1983), Pickerill et al. (1988), King et al. (1988) and Williams (1990).

The specimen described herein was collected from talus material of the Beach Formation of the Bell Island Group in a coastal section exposed between Dominion Pier and Scotia Pier on the southeastern shore of Bell Island (Fig. 1). The Beach Formation is essentially Tremadoc in age, though, as noted by Pickerill and Fillion (1983), the Tremadoc-Arenig boundary may possibly be located within its upper horizons. The essentially Tremadocian age is apparently supported by the discovery of a single graptolite specimen probably belonging to the Rhabdinoporaflabelliformis group (S.H. Williams, personal communication, 1989).

The Beach Formation, as indeed the entire sequence constituting the Bell Island and Wabana groups, is essentially a siliciclastic sequence of interbedded sandstones, siltstones, shales and ironstones. As outlined by Ranger et al. (1984), Pickerill et al. (1988) and Fillion and Pickerill (1990), these strata were deposited in a storm-dominated shelf and deltaic environment.

\section{SYSTEMATIC PALICHNOLOGY}

Ichnogenus Arthrophycus Hall, 1852

Arthrophycus isp.

(Fig. 2)

\section{Material}

Single specimen from the Beach Formation approximately midway between Dominion Pier and Scotia Pier, southeastem shore of Bell Island, Conception Bay, eastern Newfoundland

*Present address: Département de Géologie, Université d'Ottawa, Ottawa, Ontario K1N 6N5, Canada 


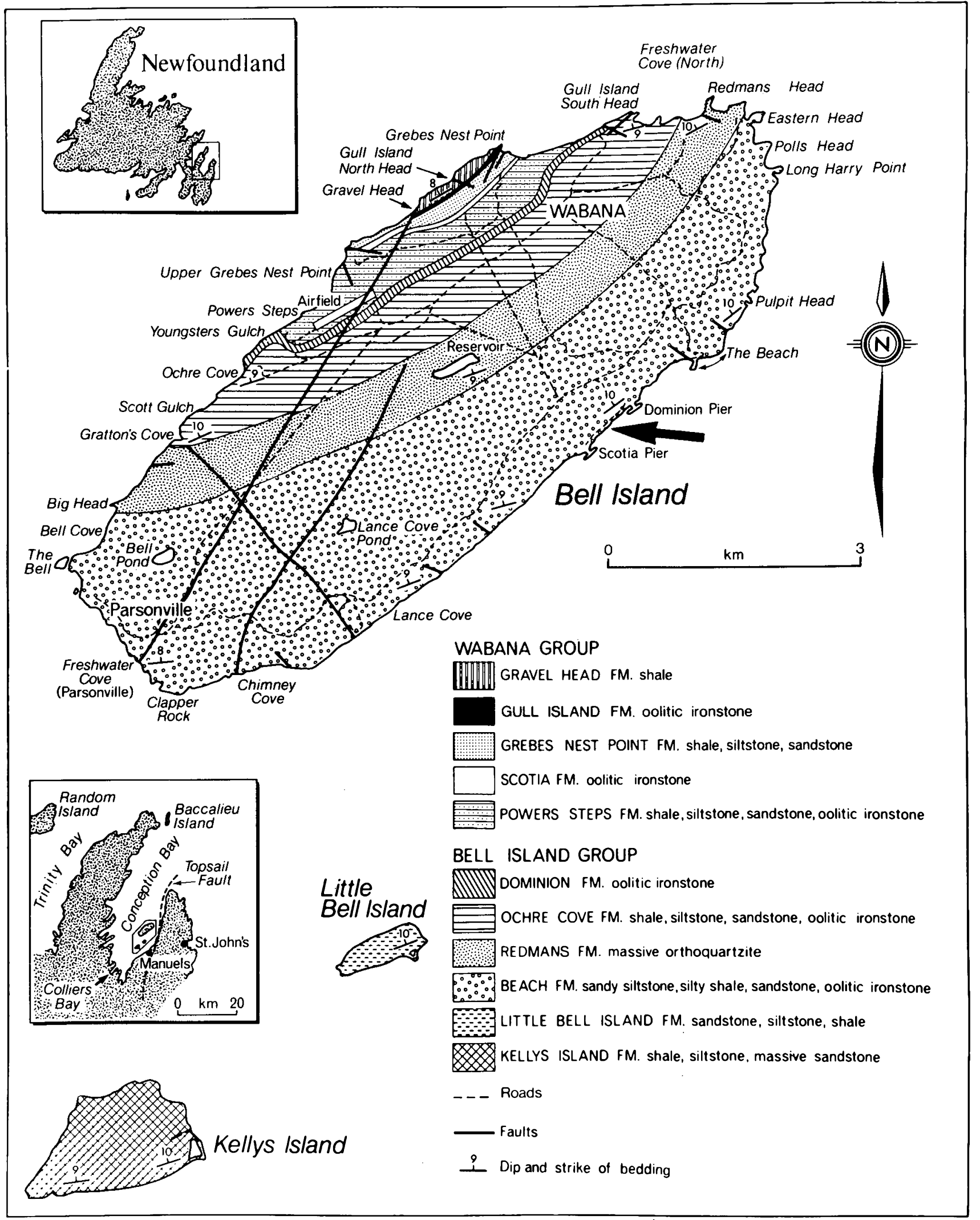

Fig. 1. Location and simplified geological map (after Ranger et al., 1984) of Bell, Little Bell and Kellys islands, Conception Bay, eastern Newfoundland. Arthrophycus isp. location is denoted by arrow. 


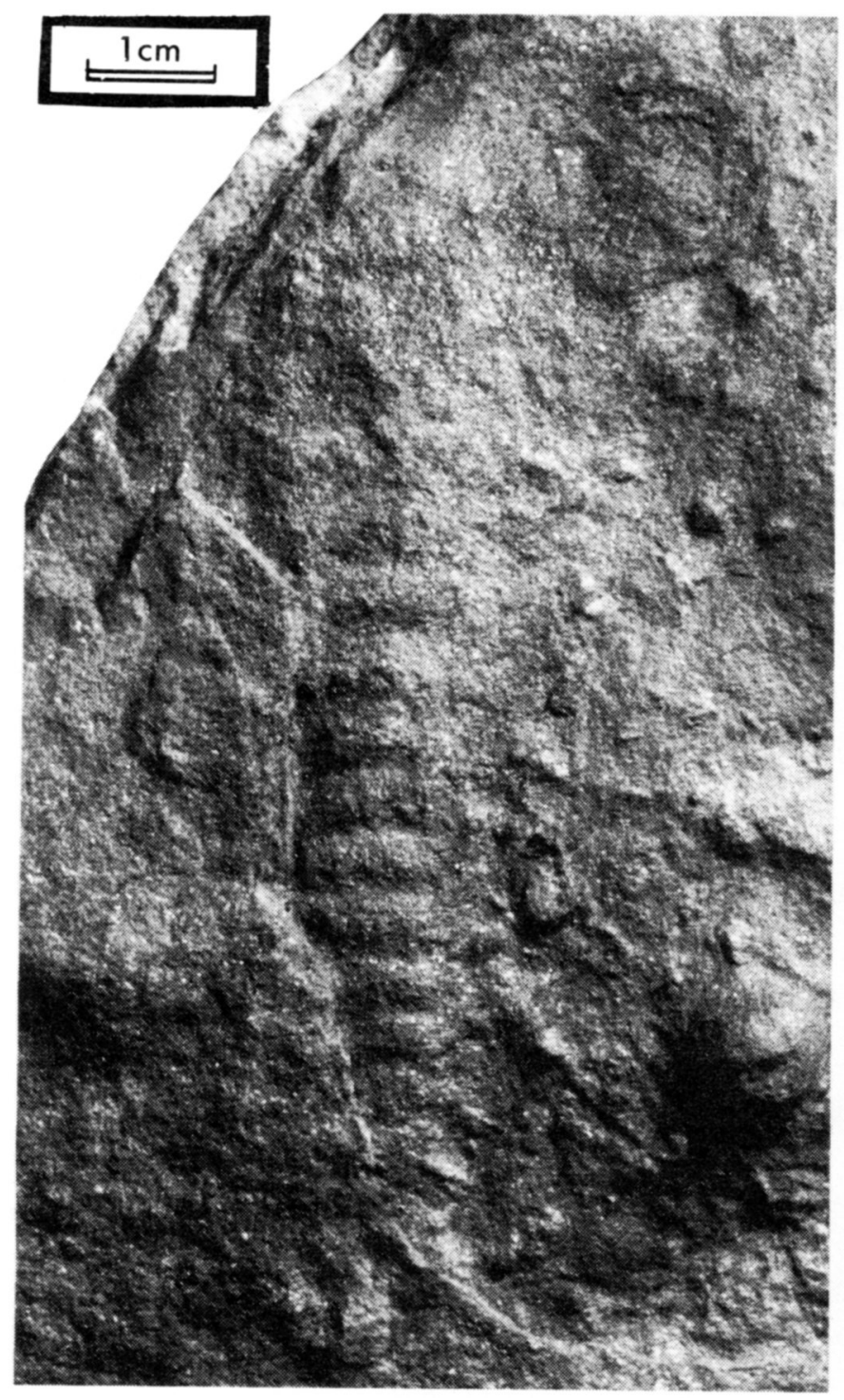

Fig. 2. Arthrophycus isp. preserved on a sandstone sole from the Beach Formation, Bell Island Group, Bell Island, Conception Bay, eastem Newfoundland. Specimen GSC 98485.

(Fig. 1). The specimen is reposited at the Geological Survey of Canada, Ottawa, Ontario, GSC 98485.

\section{Description}

The specimen is preserved in convex relief on the sole of a 35 to $45 \mathrm{~mm}$-thick slab of parallel- and cross-laminated, finegrained, micaceous sandstone and mudstone. It comprises an imperfectly preserved, straight, horizontal lower surface expression of a presumed endichnial unbranched burrow, $70 \mathrm{~mm}$ in length, and where observable, at least $12 \mathrm{~mm}$ in width. The burrow is characterized by unornamented, transverse, 2.5 to 3 $\mathrm{mm}$-wide, gently convex ridges separated by $1 \mathrm{~mm}$-wide, flatbottomed grooves. Burrow margins cannot be discerned as both the ridges and grooves pass gradationally into the enclosing rock. Vertical relief is only in the order of a few millimetres. Associated trace fossils on the same slab include Calycraterion samsonowiczi Karaszewski, 1971, Rosselia Dahmer, 1937 and Skolithos Haldeman, 1840.

\section{Remarks}

The ichnogenus Arthrophycus was erected by Hall (1852) for simple or branched burrows "...marked by ridges or articulations..." (Hall, 1852, p.4) from the Silurian Medina Formation of western New York. Seilacher (1955) considered it to be a junior synonym of Phycodes Richter, 1850, but most subsequent authors have regarded the two as separate and distinctive ichnogenera (e.g., Häntzschel, 1962, 1975; Osgood, 1970; Pickerill et al., 1984). Osgood (1970) has outlined the several differences between the two ichnogenera which we also consider should both be retained.

With better and more completely preserved material than that described here, Arthrophycus is commonly branched to form bunches or bundles of burrows each of which, however, still retains the distinctive transverse articulations (e.g., Hall, 1852, pl. 2, fig. 1a; Lessertisseur, 1955, pl. VII, figs. 9, 10; Seilacher, 1969, pl. 1, p. 121; Baldwin, 1977, pl. 2a, p. 22; Turner and Benton, 1983, fig. 4A, p. 452; Pickerill et al., 1984, fig. 2a, p. 252). Commonly with such examples the individual burrows also possess a narrow central furrow or depression which runs longitudinally along their length. Hall $(1852$, p. 5) referred to this latter feature as a "...longitudinal depressed line...." The presence of bundles and the central furrow is, however, unnecessary for ichnogeneric assignment to Arthrophycus. Indeed, several additional authors (e.g., Książkiewicz, 1977, pl. 1, figs. 8, 14; Legg, 1985, pl. 4E, p. 160; Durand, 1985, pl. 4, figs. 3, 4; Bjerstedt, 1987, fig. 8.1, p. 876) have identified the ichnogenus based on single, commonly incomplete burrows that exhibit neitherbunching nor the central furrow. Such is the case here where even though the specimen is poorly preserved and incomplete, we are confident with respect to its ichnogeneric assignation. In view of the fact that only a single specimen has, to date, been discovered, we are reluctant to attempt an ichnospecific assignment.

Arthrophycus is generally regarded as the feeding burrow of an arthropod or sedentary polychaete annelid and ranges in age from Cambrian to Tertiary (Sarle, 1906; Häntzschel, 1975; Ksiazkiewicz, 1977). To date it has only been reported from marine sequences.

\section{DISCUSSION}

Fillion and Pickerill (1990) recorded 40 ichnogenera, represented by 111 ichnospecies, and 5 vernacular ichnotaxa from the Bell Island and Wabana groups. The Beach Formation contained 26 ichnogenera, 78 ichnospecies and 2 vernacular ichnotaxa and represented the most diverse formation (ichnologically) of the entire sequence. In part this high diversity resulted from the considerable range of lithologies constituting the formation, conducive to preservation of trace fossils by toponomic processes, and the variety of marginal and shallow marine environments represented within it (see Ranger, 1979; Ranger et al., 1984; Pickerill et al., 1988; Fillion and Pickerill, 1990). The occurrence of Arthrophycus, as described herein, further in- 
creases the ichnogeneric diversity of this formation.

The "European" aspect of the trace fossils within the Bell Island and Wabana groups was first noted by Seilacher and Crimes (1969) and later by Bergström (1976) and Pickerill and Fillion $(1983,1984)$. These publications essentially emphasized the remarkable similarity of trilobite-produced ichnospecies of Cruziana present in eastern Newfoundland and coeval strata in England and Wales (Crimes, 1970; 1975), northwest Spain (Baldwin, 1977), Brittany and Morocco (Blaise and Bouyx, 1980) and Portugal (Romano, 1982). More recently Fillion and Pickerill (1990) extended this correlation to include coeval sequences in Brittany (Durand, 1985) and Argentina (Alonso and Marquillas, 1981; Alonso et al., 1982; Manca, 1986). Fillion and Pickerill (1990) also noted the remarkable similarity of additional non-trilobite produced ichnogenera mutual to eastern Newfoundland and several of these successions. Unlike several of these sequences, however, Fillion and Pickerill (1990) drew attention to the fact that the ichnogenera Arthrophycus Hall, 1852, Daedalus Rouault, 1850 and Volkichnium Pfeiffer, 1965 were apparently absent from eastem Newfoundland. It must be noted, however, that Fillion and Pickerill (1990) did record the ichnogenus Heimdallia Bradshaw, 1981 from eastern Newfoundland and pointed out that comparison of types may render it a junior synonym of Daedalus. The apparent absence of Daedalus in eastern Newfoundland may, therefore, be unreal. Additionally, Volkichnium is also a candidate for taxonomic reassessment, particularly as this simple stellate trace was not vertically sectioned when originally erected by Pfeiffer (1965), and it could well prove to be a junior synonym of one of several previously defined stellate ichnogenera. Also, Volkichnium is only a rarely occurring ichnotaxon in only two of the aforementioned sequences.

Thus, until now, the surprising but apparent omission from the eastem Newfoundland sequence was Arthrophycus. In the above mentioned coeval sequences, this ichnogenus occurs in Spain, Portugal, Brittany, Morocco and Argentina and typically in abundant and monospecific and gregarious populations preserved in convex relief on sandstone soles. Indeed, preservation as isolated specimens such as that described here is not commonplace, though, for example, Ksiązikiewicz (1977), Legg (1985), Durand (1985) and Bjerstedt (1987) have described similar examples. Such occurrences as isolated individuals are, however, atypical and not clearly understood. However, the more important point to emphasize here is the actual occurrence of the ichnotaxon in eastem Newfoundland. This occurrence further corroborates the "European" aspect of the ichnofaunal assemblage as noted above.

As also pointed out by Fillion and Pickerill (1990) similarities also exist with acritarchs, trilobites and graptolites (Dean and Martin, 1978), between eastern Newfoundland and northwestem France and the Anti-Atlas mountains of Morocco (Dean 1976). Ranger (1979) and Hiscott (1982) also pointed to the remarkable similarity of Cambrian-Ordovician lithofacies and inferred depositional environments. All evidence confirms reconstructions that place the Avalon Zone of Newfoundland west of Spain during the Ordovician (Cocks and Fortey, 1982; Neuman, 1984; Dean, 1985).

\section{ACKNOWLEDGEMENTS}

We thank G. Nunn for his hospitality in Newfoundland, and A. Gomez, R. McCulloch and D. Tabor for technical assistance during preparation of this note. Reviews of the original manuscript were undertaken by L. Fahraeus and S.H. Williams who are gratefully acknowledged. Financial support was provided by a Natural Sciences and Engineering Council of Canada operating grant OGP0003857 to R.K.P. and a University of Liverpool travel grant to P.J.B., both of which are gratefully acknowledged. Use of isp. instead of ichnosp. as the standard abbreviation for ichnospecies follows the suggestion of R.G. Bromley.

ALONSO, R.N. and MARQUILLAS, R.A. 1981. Trazas fosiles de la Formacíon Campanario (Grupo Mesón, Cámbrico) en el norte Argentino. Consideraciones ambiantales y cronológicas. Revista del Instituto de Ciencias Geologicas, 4, pp. 95-110.

ALONSO, R.N., MALANCA, S., and SUREDA, R.J. 1982. Consideraciones sobre el Ordovícico en la Sierra de Aguilar, Jujuy, Argentina. Revista del Instituto de Ciencias Geologicas, 5, pp. 1-21.

BALDWIN, C.T. 1977. The stratigraphy and facies associations of trace fossils in some Cambrian and Ordovician rocks of northwestern Spain. In Trace fossils 2. Edited by T.P. Crimes and J.C. Harper. Geological Joumal, Special Issue 9, pp. 9-40.

BERGSTRÖM, J. 1976. Lower Palaeozoic trace fossils from eastem Newfoundland. Canadian Journal of Earth Sciences, 13, pp. 1613 1633.

BJERSTEDT, T.W. 1987. Latest Devonian - earliest Mississippian nearshore trace-fossil assemblages from West Virginia, Pennsylvania, and Maryland. Journal of Paleontology, 61, pp. 865-889.

BLAISE, J. and BOUYX, E. 1980. Les séries cambro-ordoviciennes à Cruziana et le problème de l'extension septentrionale des platesformes "périgondwaniennes" durant le Paléozoïque inférieur. Académie des Sciences, Compte Rendus Hebdomadaires des Séances, Série D, Science Naturelles, Paris, 291, pp. 793-796.

BRADSHAW, M.A. 1981. Paleoenvironmental interpretations and systematics of Devonian trace fossils from the Taylor Group (lower Beacon Supergroup), Antarctica. New Zealand Joumal of Geology and Geophysics, 24, pp. 615-652.

COCKS, L.R.M. and FORTEY, R.A. 1982. Faunal evidence for oceanic separations in the Palaeozoic of Britain. Journal of the Geological Society of London, 139, pp. 465-478.

CRIMES, T.P. 1970. Trilobite tracks and other trace fossils from the Upper Cambrian of North Wales. Geological Journal, 7, pp. 47-68. 1975. The stratigraphical significance of trace fossils. Chapter 7. In The study of trace fossils. Edited by R.W. Frey. SpringerVerlag, New York, pp. 109-130.

DAHMER, G. 1937. Lebensspuren aus dem Taunusquarzit und den Siegener Schichten (Unterdevon). Preussische Geologische Landesanstalt zu Berlin, Jahrbuch 57, pp. 523-539. [For 1936].

DEAN, W.T. 1976. Some aspects of Ordovician correlation and trilobite distribution in the Canadian Appalachians. In The Ordovician System. Edited by M.G. Bassett. University of Wales Press and National Museum of Wales, Cardiff, pp. 227-250.

1985. Relationships of Cambrian-Ordovician faunas in the Caledonide-Appalachian Region, with particular reference to trilobites. In The tectonic evolution of the Caledonide-Appalachian Orogen. Edited by R.A. Gayer. Friedrich. Vieweg and Sohn, Braunschweig/Wiesbaden, pp. 17-47.

DEAN, W.T. and MARTIN, F. 1978. Lower Ordovician acritarchs and trilobites from Bell Island, eastern Newfoundland. Bulletin of the 
Geological Survey of Canada, 284, pp. 1-35.

DURAND, J. 1985. Le Grès Armoricain. Sédimentologie-Traces fossiles. Milieux de dépôt. Centre Armoricain d'Etude structurale des Sociles, Mémoires et Documents 3, 150 p.

FILLION, D. and PICKERILL, R.K. 1990. Ichnology of the Upper Cambrian? to Lower Ordovician Bell Island and Wabana groups of eastern Newfoundland, Canada. Palaeontographica Canadiana, 7, $119 \mathrm{p}$.

HALDEMAN, S.S. 1840. Supplement to number one of "a monograph of the Limniades, or freshwater univalve shells of North America", containing descriptions of apparently new animals in different classes, and the names and characters of the subgenera in Paludina and Anculosa. Philadelphia (?private publication), $3 \mathrm{p}$.

HALL, J. 1852. Palaeontology of New York. Volume II. Containing descriptions of the organic remains of the Lower Middle Division of the New York System, (equivalent in part to the Middle Silurian rocks of Europe). C. van Benthuysen, Albany, 362 p.

HÄNTZSCHEL, W. 1962. Trace fossils and problematica. In Treatise on invertebrate paleontology, part W, Miscellanea. Edited by R.C. Moore. Geological Society of America and University of Kansas Press, New York and Lawrence, Kansas, pp. W177-W245.

-1975. Trace fossils and problematica. In Treatise on invertebrate paleontology, part W, Miscellanea, supplement I. Edited by C. Teichert. Geological Society of America and University of Kansas Press, Boulder, Colorado and Lawrence, Kansas, pp. W1-W269.

HISCOTT, R.N. 1982. Tidal deposits of the Lower Cambrian Random Formation, eastern Newfoundland: facies and paleoenvironments. Canadian Journal of Earth Sciences, 19, pp. 2028-2042.

KARASZEWSKI, W. 1971. Some fossil traces from the Lower Liassic of the Holy Cross Mts., Central Poland. Bulletin de l'Académie Polonaise des Sciences, Série des Sciences de la Terre, 19, pp. 101 105.

KING, A.F., BOYCE, W.B., PICKERILL, R.K., and WILLIAMS, S.H. 1988. The St. John's region. Fifth International Symposium on the Ordovician System, St. John's, Newfoundland, Canada. Field Excursion Guide Book, 39 p.

KSIAŻKIEWICZ, M. 1977. Trace fossils in the flysch of the Polish Carpathians. Palaeontologia Polonica, 36, pp. 1-208.

LEGG, I.C. 1985. Trace fossils from a Middle Cambrian deltaic sequence, North Spain. In Biogenic structures: their use in interpreting depositional environments. Edited by H.A. Curran. Society of Economic Paleontologists and Mineralogists, Special Publication 35, pp. 151-165.

LESSERTISSEUR, J. 1955. Trace fossiles d'activité animale et lcur signification paléobiologique. Société Géologique de France, Mémoire, nouvelle série, 74, pp. 1-150.

MANCA, N. DEL VALLE. 1986. Caracteres icnológicos de la Formación Campanario (Cámbrico superior) en Salta y Jujuy. Ameghiniana, 23, pp. 75-87.

NEUMAN, R.B. 1984. Geology and paleobiology of islands in the Ordovician Iapetus Ocean: Review and implications. Bulletin of the Geological Society of America, 95, pp. 1188-1201.

OSGOOD, R.G., JR. 1970. Trace fossils of the Cincinnati area. Palaeontographica Americana, 6, pp. 277-444.

PFEIFFER, H. 1965. Volkichnium volki n. gen., n. sp. (Lebens Spuren) aus den Phycoden -Schichten Thüringens. Geologie, 14, pp. 1266-
1268.

PICKERILL, R.K. and FILLION, D. 1983. On the Tremadoc-Arenig and Lower-Upper Tremadoc boundaries in the Bell Island Group, Conception Bay, eastern Newfoundland. Maritime Sediments and Atlantic Geology, 19, pp. 21-30.

1984. Occurrence of Rusophycus morgati in Arenig strata of Bell Island, eastem Newfoundland. Journal of Paleontology, 58, pp. 274-276.

PICKERILL, R.K., ROMANO, M., and MELÉNDEZ, B. 1984. Arenig trace fossils from the Salamanca area, western Spain. Geological Journal, 19, pp. 249-269.

PICKERILL, R.K., FILLION, D., and RANGER, M.J. 1988. Lower Ordovician deltaic, shallow marine and ironstone deposits and associated trace fossils, Bell Island. Geological Association of Canada/Mineralogical Association of Canada, Field Trip Guide Book A7, 81 p.

RANGER, M.J. 1979. The stratigraphy and depositional environment of the Bell Island Group, the Wabana Group and the Wabana Iron Ores, Conception Bay, Newfoundland. Unpublished M.Sc. thesis, Memorial University of Newfoundland, Canada, $216 \mathrm{p}$.

RANGER, M.J., PICKERILL, R.K., and FILLION D. 1984. Lithostratigraphy of the Cambrian?-Lower Ordovician Bell Island and Wabana groups of Bell, Little Bell and Kellys islands, Conception Bay, eastem Newfoundland. Canadian Journal of Earth Sciences, 21, pp. 1245-1261.

RICHTER, R. 1850. Aus der thüringischen Grauwacke. Deutsche Geologische Geseuschalt Zeitschrift, 2, pp. 198-206.

ROMANO, M. 1982. The Cambrian-Ordovician boundary in Spain, Portugal and north-west France. In The Cambrian-Ordovician boundary: sections, fossil distributions, and correlations. Edited by M.G. Bassett and W.T. Dean. National Museum of Wales, Geological Series 3, pp. 71-75.

ROUAULT, M. 1850. Note préliminaire sur une nouvelle formation découverte dans le terrain silurien inférieur de la Bretagne. Bulletin de la Société Géologique de France, Série 2, 7, pp. 724-744.

SARLE, C.J. 1906. Arthrophycus and Daedalus of burrow origin. Proceedings of the Rochester Academy of Science, 4, pp. 203-210.

SEILACHER, A. 1955. Spuren und Fazies im Unterkambrium. In Beiträge zur Kenntnis des Kambriums in der Salt Range (Pakistan). Edited by O.H. Schindewolf and A. Seilacher. Akademie der Wissenschaften und der Literatur zu Mainz, mathematisch-naturwissenschaftliche Klasse, Abhandlungen 10, pp. 373-399.

- 1969. Sedimentary rhythms and trace fossils in Paleozoic sandstones of Libya. In Geology, archaeology and prehistory of the southwestem Fezzan, Libya. Edited by W.H. Kanes. Petroleum Exploration Society of Libya, Eleventh Annual Field Conference, pp. 117-123.

SEILACHER, A. and CRIMES, T.P. 1969. "European" species of trilobite burrows in eastem Newfoundland. In North Atlantic geology and continental drift. Edited by M. Kay. American Association of Petroleum Geologists, Memoir 12, pp. 145-148.

TURNER, B.R. and BENTON, M.J. 1983. Paleozoic trace fossils from the Kufra Basin, Libya. Journal of Paleontology, 57, pp. 447-460.

WILLIAMS, S.H. 1990. An Arenig graptolite from Bell Island, eastern Newfoundland - its biostratigraphic and paleogeographic significance. Atlantic Geology, 26, pp. 43-55. 